\title{
Research on environmental sustainable development from the perspective of ecological science and technology innovation
}

\author{
$\mathrm{Na} \mathrm{Li} i^{1 *}$ \\ ${ }^{1}$ Wuhan University of Science and Technology, Wuhan, China
}

\begin{abstract}
At present, the prominent problems of ecological environment and the negative environmental effects of modern science and technology promote the development of scientific and technological innovation in the direction of ecology. The ecological concept of scientific and technological innovation can help the battle of pollution control and promote the reconciliation between man and nature. The ecological orientation of scientific and technological innovation in environmental sustainable development has some problems, such as unclear development orientation, insufficient innovation ability, lack of ecological concept, and insufficient public participation. Therefore, we should clarify the ecological orientation of scientific and technological innovation, improve innovation ability, promote the reform of environmental management system, and strengthen ecological moral education.
\end{abstract}

\section{Introduction}

Technology is an important productive force, and innovation is the first driving force leading the development. The sustainable development of ecological environment is the fundamental plan for the sustainable development of the Chinese nation. There is an important connection between scientific and technological innovation and sustainable development of ecological environment. Science and technology has a profound impact on people's production and life, but it also brings a series of ecological environment problems, which forces scientific and technological innovation to develop in the direction of ecology, vigorously develop ecological environment technology, and further promote the innovative development of ecological civilization.

\section{The connotation explanation of the ecological concept of scientific and technological innovation}

As for the connotation of ecological concept of scientific and technological innovation, Zhao Haiyue believes that "ecological concept of scientific and technological development is not economic development in a simple sense, but a three-dimensional complex system composed of society, ecology and economy, which is interconnected and interacted with each other." ${ }^{[1]} \mathrm{Fu}$ Xiaohua believes that "the ecological concept of scientific and technological innovation is a new innovation system infiltrated from ecology to scientific and technological innovation, so as to guide the coordinated development of scientific and technological innovation in the direction of beneficial to resources, environmental protection and the virtuous cycle between it and economic, social and environmental systems" ${ }^{[2]}$ Chen Cuifang believes that "ecological concept of science and technology is the process and result of regarding science and technology as a complex ecosystem, integrating the principles and methods of ecology into the whole scientific and technological activities such as scientific and technological research, scientific and technological design, scientific and technological application and scientific and technological management, guiding and ensuring science and technology to follow ecological principles and ecological laws, and ultimately protecting the environment and maintaining ecological balance."[3] To sum up, the ecological concept of scientific and technological innovation reflects the role of scientific and technological progress in transforming the ecological environment, repairing the relationship between man and nature, and realizing the sustainable development of the environment. Therefore, it is very necessary to realize the ecological concept of scientific and technological innovation.

\section{The necessity of the development of scientific and technological innovation in the direction of ecology}

\subsection{The prominent problems of ecological environment in China need transformation and upgrading of scientific and technological innovation}

First, water resources are scarce, and water environment pollution is still serious. Compared with other countries, China's water resources are far lower than the world's per

* Corresponding author: 15171898972@163.com 
capita water resources. China has very little water per person, as shown in Figure 1. At the same time, the current situation of water environment pollution in China is still very serious. Nearly half of the major rivers and lakes in the country are seriously polluted, and nearly $90 \%$ of the urban water quality exceeds the standard, which increases the difficulty of water environment treatment in China.

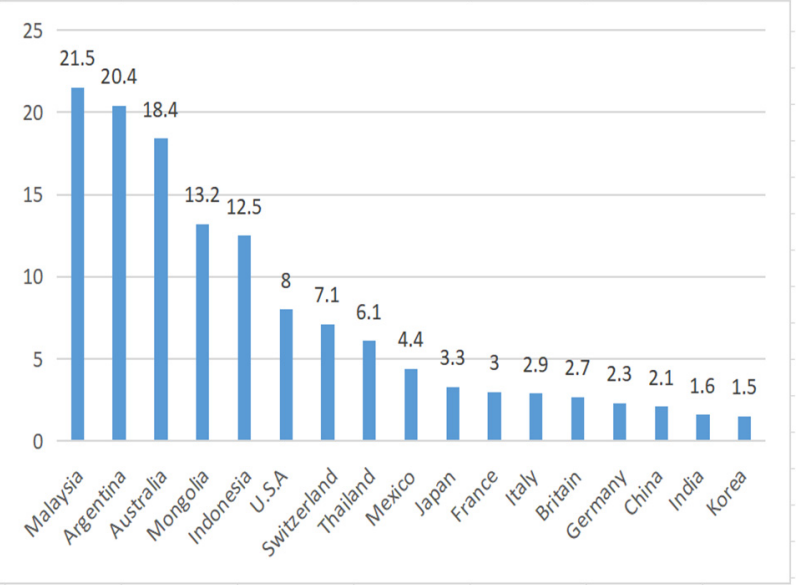

Figure 1. Fresh water per capita in different countries

Second, the amount of industrial solid waste is increasing year by year, and the utilization and disposal rate of waste is relatively low. As shown in table 1 ,from 2016 to 2019, the production of general industrial solid waste increased year by year, from 3.71 billion tons in 2016 to 4.41 billion tons in 2019 . The production of industrial hazardous waste increased from 52.95 billion tons in 2016 to 81.6 billion tons in 2019 . The amount of industrial waste disposal is not high compared with the amount of waste generated, which indicates that the industrial solid waste disposal technology needs further reform and innovation.

Table1. Output and disposal of industrial solid waste

\begin{tabular}{|c|c|c|c|c|}
\hline Year (Billion tons) & 2016 & 2017 & 2018 & 2019 \\
\hline $\begin{array}{c}\text { Production of general industrial solid } \\
\text { waste }\end{array}$ & 37.1 & 38.7 & 40.8 & 44.1 \\
\hline $\begin{array}{c}\text { Disposal volume of general industrial } \\
\text { solid waste }\end{array}$ & 8.5 & 9.4 & 10.3 & 11.0 \\
\hline $\begin{array}{c}\text { Production of industrial hazardous } \\
\text { waste }\end{array}$ & 5219.5 & 6581.3 & 7470.0 & 8126.0 \\
\hline $\begin{array}{c}\text { Comprehensive utilization and } \\
\text { disposal of industrial hazardous waste }\end{array}$ & 4317.2 & 5972.7 & 6788.5 & 7539.3 \\
\hline
\end{tabular}

Finally, as shown in figure 2, The problem of urban air pollution is still very serious. According to the data published in the bulletin on the state of China's ecological environment (2019), in 2019, 157 of the 337 cities in China met the air quality standards, accounting for $46.6 \%$ of the total number of cities. The air quality of 180 cities exceeded the standard, accounting for $53.4 \%$.

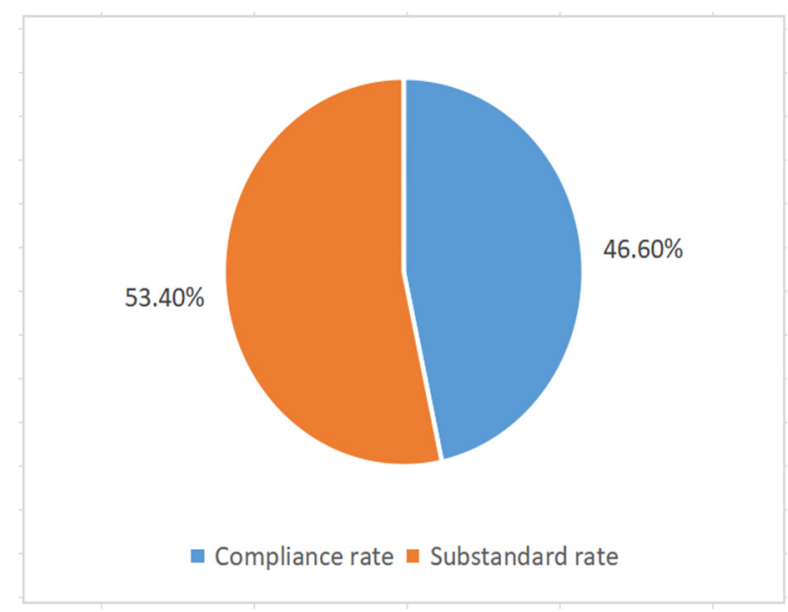

Figure 2. Air quality standards of 337 cities in 2019

\subsection{The negative environmental effects of modern science and technology give birth to ecological science and technology}

In the past, human beings only paid attention to the economic benefits of scientific and technological transformation, over exploited natural resources, destroyed the balance of the ecosystem, factory pollutant emissions, increasing garbage, oil leakage, optical pollution, overfishing, illegal trafficking in wild animals and so on accelerated the deterioration of the environment, and the relationship between human and nature gradually became disharmonious with the progress of science and technology. It is because of the negative effects of science and technology that China accelerates the construction of green technology innovation system and provides an important scheme for environmental sustainable development.

\section{The role of ecological science and technology innovation in promoting environmental sustainable development}

\subsection{It has played a supporting role in the battle of pollution control}

AS shown in table 2, in order to fight the battle of pollution prevention and control, through large-scale scientific observation and experimental research, China adopts the way of diverse technology integration, and adopts a series of Eco-Environmental Science and technology in water pollution, air pollution, soil pollution, ecological restoration, solid waste utilization, etc. And forms a broad scientific consensus, which provides support for pollution control and fighting the battle of pollution prevention and control. 
Table2. Application of ecological environment science and technology

\begin{tabular}{|c|c|}
\hline Name of pollution prevention and control & $\begin{array}{l}\text { Achievements in the application of science } \\
\text { and technology }\end{array}$ \\
\hline $\begin{array}{l}\text { Major science and technology projects for } \\
\text { water pollution control and treatment }\end{array}$ & $\begin{array}{l}\text { The key technologies of water "source } \\
\text { control and emission reduction", water "burden } \\
\text { reduction and restoration", and comprehensive } \\
\text { regulation of water environment in the basin }\end{array}$ \\
\hline $\begin{array}{l}\text { Key project of "Research on the causes and } \\
\text { control technology of air pollution" }\end{array}$ & $\begin{array}{l}\text { Monitoring, forecasting and early warning } \\
\text { technology, pollution source whole process } \\
\text { control technology, air quality improvement } \\
\text { management support technology and air } \\
\text { pollution joint prevention and control } \\
\text { technology }\end{array}$ \\
\hline $\begin{array}{l}\text { Key project of "causes and treatment } \\
\text { technology of site soil pollution" }\end{array}$ & $\begin{array}{l}\text { Soil pollution formation mechanism, } \\
\text { monitoring and early warning, risk management } \\
\text { and control, remediation, safe use and other } \\
\text { technologies }\end{array}$ \\
\hline $\begin{array}{l}\text { Key project of "Research on restoration and } \\
\text { protection of typical fragile ecology" }\end{array}$ & $\begin{array}{l}\text { Ecological monitoring and assessment } \\
\text { technology, forest and wetland ecological } \\
\text { protection and restoration technology in } \\
\text { Northeast China, comprehensive management } \\
\text { technology of sandy land in northern sandy area, } \\
\text { ecological protection and restoration technology } \\
\text { in middle and upper reaches of Yangtze River, } \\
\text { etc }\end{array}$ \\
\hline "Solid waste recycling" key project & $\begin{array}{l}\text { Large industrial solid waste building } \\
\text { materials utilization, domestic waste } \\
\text { incineration power generation, heavy metal solid } \\
\text { waste safe disposal technology }\end{array}$ \\
\hline
\end{tabular}

4.2 The ecological innovation of science and technology promotes the reconciliation of the relationship between man and nature

The real reconciliation of the relationship between man and nature depends on man's initiative to understand and transform nature, that is, scientific and technological innovation. Science and technology is the direct cause of ecological crisis. If we redefining the direction of scientific and technological innovation and integrate the ecological value and environmental protection concept into scientific and technological innovation, the development of science and technology will be in the direction of coordinating the relationship between human and nature, and finally realize the sustainable development of the whole society.

\section{The dilemma of scientific and technological innovation in promoting environmental sustainable development}

\subsection{The positioning of scientific and technological innovation is not comprehensive, and the concept of ecological definition of scientific and technological innovation is vague}

Although the government has issued relevant policy planning and guidance to promote the ecological of scientific and technological innovation, the concept of protecting the ecological environment has not become the main direction of scientific and technological innovation. For the ecological concept of scientific and technological innovation, this paper puts forward a variety of concepts, such as intermediate technology, soft technology, diversity technology, green technology, environmental technology, environmental protection technology and so on. The concept used is too diversified, easy to cause confusion, difficult to form a unified theoretical standard, is not conducive to the in-depth study of the problem.

\subsection{Lack of innovation ability and difficult transformation of traditional industries}

Advanced science and technology does not mean that a country's independent innovation ability is developed. Even if the more advanced technology is, without the support of innovation, a series of environmental problems brought by science and technology can not be solved. At present, there are still many traditional industries that have not achieved transformation and upgrading, which is the outstanding performance of the lack of innovation ability. Take China's heavy polluting industry as an example, the gases, waste water and waste residue discharged by factories cause serious pollution to the environment, and some pollution is irreversible. Although China's manufacturing industry occupies a certain position in the last century, a large amount of waste from factories can easily cause direct impact on the environment. It is precisely because of the lack of innovation ability that the damage to the environment is becoming more and more serious due to the inability of traditional industries to transform and upgrade rapidly.

\subsection{The soft environment of innovation is insufficient and the ecological concept is missing}

Generally speaking, science and technology innovation environment can be divided into hard environment and soft environment. The hard environment consists of material environment, management system and personnel, while the soft environment consists of humanistic environment, flexible research direction and evaluation system. In terms of the soft environment for scientific and technological innovation, although China has formulated a variety of scientific and technological development plans and strategies, which provide policy support for scientific and technological innovation. In the development of green science and technology and the concept of ecological science and technology, there are still insufficient understanding, ecological awareness and other problems, resulting in the scientific research of the internal cultural atmosphere is not strong enough, resulting in the construction of soft environment values and ecological view of the lack of propaganda.

\subsection{The public scientific literacy is relatively low, and the public participation consciousness is insufficient}

Public scientific literacy plays a key role in the process of innovation and development. Scientific literacy refers to the public's attitude towards science and understanding of 
scientific and technological knowledge, which can reflect a country's cultural level and education level. The level of public scientific literacy in China has improved on the whole, but there is still a big gap compared with developed countries, which is manifested in the lack of scientific spirit, less opportunities to accept popular science knowledge, and low level of education. On the one hand, the lack of scientific literacy will affect the public's acceptance and understanding of science and technology, and it is easy to misunderstand science, thus undermining the enthusiasm of scientists; On the other hand, most of the public seldom participate in science popularization activities, only see the advantages of science and technology, but seldom consider the ecological problems hidden in science and technology. ${ }^{[4]}$

\section{The path of environmental sustainable development from the perspective of scientific and technological innovation}

\subsection{Clarify the orientation of ecological science and technology innovation and give play to the leading role of the government}

The government should give strong support and attach great importance to the ecological direction of scientific and technological innovation. In terms of policy, it should incline to the ecological development of science and technology, give financial support to experts who carry out public technology research, give preferential policies and taxes to enterprises who implement the ecological development of science and technology, and encourage the ecological research and industrial development of science and technology development ${ }^{[5]}$. In law, the implementation of the main responsibility of scientific and technological innovation requires enterprises to shoulder the obligation of environmental protection and establish a new ecological concept.

\subsection{Improve innovation ability and maintain technological achievements of scientific and technological innovation}

Establish a technology innovation system with enterprise as the main body and the combination of production, learning and research, and improve the comprehensive application ability of innovation. Meanwhile, we should maintain the achievements of scientific and technological innovation and introduce modern green technologies such as clean production technology, energy saving technology and recycling technology in improving production mode. We should enhance the level of the construction of the intelligent environment, firmly grasp the revolution with information technology, biotechnology and other high and new technologies as the core, and promote scientific and technological innovation towards the road of intelligence, intelligence and green.

\subsection{Promoting the reform of environmental management system}

Environmental management system is an organic whole which is established in accordance with certain rules and regulations in order to improve the environment and reduce pollution. We should attach importance to the support and guarantee function of the environmental management system, so as to make the ecological science and technology innovation as a whole, promote each other and complement each other.

\subsection{Improve the ability of science popularization and strengthen the education of Ecological Morality}

Integrating the concept of ecological science and technology into the work of science popularization education can make people understand the whole picture of scientific development, improve people's scientific awareness of caring for the environment, protecting the environment and treating nature well, and make the mass power become the key force of ecological science and technology innovation. Strengthening ecological moral education can start with school education, mass media, legal measures, etc. to cultivate people's feelings about ecological morality, strengthen the connection between man and nature, publicize the correct concept of good and evil, and help people really love.

\section{References}

1. Zhao Haiyue, Kang Xibin. How to realize the ecological development of science and technology [J]. People's forum, 2018, (16): 148-149.

2. Fu Xiaohua. Analysis of ecological science and technology innovation from sustainable development values [J]. Scientific management research, 2006, 4144.

3. Chen Cuifang. On the connotation and basic characteristics of science and technology ecology [J]. Science and technology management research, 2014, (19): 224-228.

4. Guo Qijun, Zhang Dinghui, Zhang Hui. On the importance of green technology in the construction of ecological civilization [J]. Land greening, 2014, (8): 40-41.

5. Liang Ye. Ecological value of scientific and technological innovation $[\mathrm{J}]$. Journal of Hunan University of administration, 2018, (3), 27-32. 